\title{
The Transformation of the Images of Japanese Women in America (Selected Literature from 1853 to 1953)
}

\author{
Li Ni
}

\begin{abstract}
From Cho Cho san in Madame Butterfly (1898) to Sayuri in the modern bestseller Memoirs of a Geisha (1997), the image of Japanese woman in America seemingly has always been that geisha girl - beautiful, gentle, obedient and child-like woman. This stereotype roots deeply among the American readers and perfectly embodies the Oriental fantasy the Americans have toward Japanese women. However, is it true that the image of Japanese woman in America has always been that geisha girl without any change? In pursuit of the answer, this paper unveils the Japanese women's images through literature from 1853 to 1953 to trace the transformation of it in the Americans' view. Besides focusing on the changing process, this paper also aims to justify the relationship between national power and national gender-images of an oriental country in the context of wars against western countries.
\end{abstract}

Index Terms -American literature, images, Japanese women, orientalism.

\section{INTRODUCTION}

From Cho Cho san in Madame Butterfly (1898) to Sayuri in the modern bestseller Memoirs of a Geisha (1997), the image of Japanese woman in America seemingly has always been that geisha girl-beautiful, gentle, obedient and child-like woman. This stereotype roots deeply among the American readers and perfectly embodies the Oriental fantasy the Americans have toward Japanese women. However, is it true that the image of Japanese woman in America has always been that geisha girl without any change? In pursuit of the answer, this paper unveils the Japanese women's image through literature from 1853 to 1953 to trace the transformation of it in the Americans' view. The reason for choosing this period of time is because it is the crucial important one hundred years that the America has rapidly grown into the world's biggest power, changing from a farmland to a factory, and forming his own national identity, while at the same time, the world was undergoing unprecedented "storms", such as the highly industrialization and modernization of mankind, the sudden changes of the world pattern-imperialism and colonialism, and the frequent outbreaks of wars. Thus, besides focusing on the changing process this paper also aims to justify the relationship between national power and national gender-images of an oriental country, in the context of wars against western countries.

Manuscript received March 10, 2016; revised June 12, 2016.

$\mathrm{Li} \mathrm{Ni}$ is with International Christian University, Japan (e-mail: izni_n@126.com).

\section{SeXually AvaILable Women: 1853-1858}

Before the Black Ships incident in 1853-the Americans first stepped onto the land of Japan-the knowledge of this far eastern country was mainly acquired from the geographical tourist books, and "the images of the Japanese women were in particular influenced by the version of the oriental woman established by the writers on the Middle East" [1]. The Americans at that time were mostly considered living in a puritan life style. In contrast to their ascetical and conservative life style on sex, the local Japanese people were extremely open, which greatly challenged the Americans' moral systems. According to John Henry Preble, a young officer who arrived with Commodore Perry's squadron in February 1854, his diary recorded the first impression the Americans had toward the Japanese women and vividly reproduced the scene when they landed Yedo Bay:

The inhabitants crowded the hill, and beckoned us on shore, and by the most unmistakable signs invited our intercourse with their women. One female went so far as to raise her drapery and expose her person to us. They are either a vey lewd and lascivious people, or have catered before this, to the passion of sailors [2].

If what happened on shore was just a shock then the following scene he witnessed in temple has completely smashed his last fantasy of the oriental women.

Resting at a temple near Hakodate, he notices a pretty unmarried girl among the crowd. A man comes up to her, whispers, then takes her behind a screen five feet away: "Her companions were not slow, to show us, by the most indecent signs in which the old priest joined, what they had gone for. The women laughing heartily as though it were a first-rate joke and no uncommon occurrence to so pervert their Temples [3].

"Unmarried pretty girl", "old priest", "temple", all the keywords that should have been related to sanctity, purity and innocence now involved in the "dirtiest" sex. But what really struck the young American officer was the most casual attitude the girl's female friends had towards it. Frank Harris, one of few Victorian visitors who viewed Japanese sexual attitudes without disapproval, admitted that: "The sexuality in Japan is perhaps more marked than in any country on earth." To his delight he found the people even freer than the French: "Bit by bit I came to understand that there was not a trace of sexual modesty in Japan from one end to the other; most of the women even did not understand what Europeans meant by the concept" [4]. 


\section{The Okichi Legend}

In the background of the sexual availability of the Japanese women, happened the first love affair in the history between American man and Japanese woman. It has been remade and adapted for several times. Many love-story elements were added to this originally simple story. One of the most well-known versions was the movie The Barbarian and the Geisha filmed in 1958, made by legendary director John Huston, and had the famous Hollywood star John Wayne playing Townsend Harris, who according to the rumors was the first American to have an affair with the Japanese woman. However, from the literary point of view, the most poignant version is the novel Butterfly in the Wind written by a Japanese female writer Rei Kimura in 1999.

In 1853, the American Black Ships opened the gate of Japan. The first American Consul to Japan, Townsend Harris, was obsessed with the beauty of a geisha named Okichi. So as a bargaining chip, the 15-year-old girl was given to Harris by the local governor to be his wife. Five years later, Harris returned home ill, although Okichi was set free, under the great mental anguish and condemnation from the society she committed suicide and became a beautiful legend of Japan.

The legend of Okichi was actually nothing but another butterfly story-the most classical story model-that was favored by the westerners. Regardless of the truth that Okichi was merely one of Harris' housekeepers and was fired by him after only three days of work, people on both sides of the Pacific Ocean obviously prefer the butterfly image of her, which was beautiful but fragile, easily tossed about and bruised by the stronger forces. It reflected how the Americans would like to see the Japanese women from the very beginning and has drawn a general sketch for the mature image of the Japanese women in the Americans' view.

\section{AN ORIENTAL DOLL WITHOUT A SOUL: 1859-1893}

In this period of time, two important events happened: One was the opening of Yokohama port in 1859; the other was the Chicago World's Fair in 1893. It was actually a period that Japan grew rapidly and developed dramatically after its gate was forced to open to the world.

When the Americans first landed on this island, Japan was only a small feudal country, almost barbarian to the puritans' point of view, and women on this island were considered having no sexual modesty. But after Yokohama port opened in 1859, in addition to the success of Meiji Restoration in the following decade, which advocated Japan's departure from Asia to Europe, in the 1880s and 1890s, a number of Americans accessed into Japan. Besides the navy officers and sailors, writers, priests, traders and people from other professions also had the opportunities to personally contact with the Japanese women. Some of them even intermarried with them. Thus a new picture was presented from then on. As Ian Littlewood mentioned in his book The Idea of Japan, "Romantic love between the western man and the Japanese woman (never the other way round) had become a socially acceptable possibility, inspiring an alternative fantasy which balanced and commented on the figure of the handmaiden." [1] Thus, in this period, the Americans began to learn about Japanese woman through literature. Clive Holland's novel $M y$
Japanese Wife (1902) was a popular example. Despite of his English origin, as the first book on such themes, its influence in the English-speaking countries was very far-reaching. In this book, terms such as "toy-like", "tiny", "child-size", "doll-like", "doll's-house", "fairyland" or "make-believe" appeared on nearly every page, through which the doll image of the Japanese women was more than clear. The doll image was a classical stereotype. The reasons why the westerners favored it are analyzed from the following three aspects:

\section{A. Physically}

To the Americans, everything in Japan was so small and toy-like. From the paper house the Japanese lived in to the small amount of food they ate for every meal, the whole life of the Japanese people was like playing house. As a result, the heroine in the game was undoubtedly the doll. Moreover, Asian women look much younger than their western counterparts, so in My Japanese Wife, Holland repeatedly used the "child-woman" to describe her Japanese wife-Mousmé.

My Mousmé! with Dresden-china tinted cheeks, and tiny ways; playing at life, as it always seems to me, with the dainty grace of Japan, that idealised doll's-house land. Mousmé... [has] the delicately pretty face of a child-woman with innocent, soft eyes and finely arched brows..." [5].

\section{B. Emotionally}

Childishness also came from the thick and awkward makeup that covered all the emotion of the Japanese girl.

Our little dinner of toy-like viands is gone through...the little dancing-girl fluttered softly in.... What a droll doll she is! Childish, with an assumption of innocence which is as charming as it must be unreal. An elegant, slender little figure, full of dainty grace. Her face painted-till it looked positively funny-its whiteness hiding the native transparency of her warm-hued skin, all damask rose and nut-brown tinted. And the two little dabs of rouge-oh! With what inartistic exactness they are placed, one on either cheek....childishly pouting lips... charming baby-curls... [6].

Emotionless and heartless, like a doll, the Japanese woman was played with and manipulated by her master, the man who owned her, usually the father or the husband. She must not think, not feel, not even speak too much, but covered her natural human face and hid her innate human emotions to play the role of a beautiful Japanese doll who would do whatever her master wanted her to do. If concludes with one word, that is what Henry Norman wrote in The Real Japan, "The key to the character of the Japanese woman lies in the word obedience." [7] His statement echoes to William Elliot Griffs, who believed "the whole sum of excellences and defects of the Japanese female character arise from one all-including virtue, and the biography of a good woman is written in one word-obedience" [8].

Even in the modern times, the Japanese women still could not get rid of the emotionless doll image. As Littlewood puts it, "The shy, bowing, giggling girls who minister to the lordly westerner have no emotional or intellectual claim on him, they are merely there to do his bidding. They are butterflies in their lightness and grace but also in their lack of substance," [9] 
indicating that even though the girls were laughing or talking warmly with men, they never really felt it. It was the way how Japanese women react to men. They just did their routines under the deep-rooted virtue of "obedience". Because they were obedient and they did not have requests on men, because they never put a heart on men, so they could keep hurtless from this unfair one-way relationship. So the doll quality to the Japanese women was like a shell to escape and to shelter. It was an effective way of protecting them from the absolute obedience to men. If their hearts were not exposed, then no one could hurt them. Hence, the emotionlessness was somehow developed under the patriarchal culture of Japan, which demands the absolute obedience in man-woman relationship. It was a passive way of the Japanese women in confronting the oppression from the overwhelming male power.

\section{Morally}

As it is mentioned previously in this paper, the Japanese men and women in more than one hundred years ago were reported to have almost no any sexual modesty. Their moral system was different from it is in the modern society. Therefore, women at that time were sexually available. Like a doll lacking of moral integrity was willing to serve a man sexually. A good example in My Japanese Wife is,

A bright idea presents itself, solving my longing and loneliness.

It is Miss Hyacinth I want, and such a thing should not be impossible-in Japan [10].

The thoughts of the hero imply the sexual availability of Mousmé. Women like Mousmé were images of Japan, and their submissiveness as Littlewood puts it, "is the submissiveness of Japan. By the same token, their sexual availability reflects a Japan that is ripe for commercial exploitation" [11].

In 1893, the Chicago World's Fair gave Japan an opportunity to show and introduce itself to the outside world, meanwhile a good opportunity for the local Americans to learn about Japan and its culture. It also had set a good foundation for the "Japan craze" in the US later on. So far, In the eyes of the Americans, the Japanese women had transformed from the barbarians, the monkeys without sexual morality at the initial stage, to the geisha girls in the tea house, the dolls without a soul that amused men for fun, which was the initial sketch of the most classical image of the Japanese women, since then the most popular stereotype appeared and would be matured in the following ten years.

"It was not until 1895 did the professional writers produce works of literature based on Japan and Japanese experiences." [12] So far, the image of the Japanese women to the Americans was still left on the facet of dolls. Ten years from 1895 was the golden time of this theme in the US, in which the stereotype of the Japanese women was firmly established, and the strong influence of which has been even left to the modern days.

\section{GOLDEN Z: 1895-1904}

\section{A. A Peaceful Decade between the Wars}

Japan's growth was rapid while its ambition was even larger.
The Japanese were not satisfied with merely presenting themselves to the world. Their plan for next step was very clear-to expand overseas. In 1894, the second year after Chicago World's Fair, Japan launched the Sino-Japanese War seeking for its expansion to the Korean peninsula and northeast China. With the huge benefits of lands and money bringing by the victory of the war, Japan primarily completed the evolution from a feudal island to the world power.

This was the first war of aggression Japan launched after its rise. The targets were its counterparts in Asia. Toward this, the attitude of the United States and Western powers was acquiescence and even supportive. They thought it proved that the nation of Japanese was superior to the other Asian ethnics. This point of view could be read from the works of William Elliot Griffis. He was an avid advocate of Japan. A series of his works are perceived as having a strong decline of praising Japanese while demeaning other Asian ethnics, which consequently became a major weakness of his books that cannot be regarded as a high-leveled work. For example, in In the Mikado's Service (1901), Griffis "demeaned the Chinese, Koreans, and Formosans in order to praise the Japanese and justify Japanese expansion into those surrounding lands." [13] And "the strong praise of Japan's fighting forces presented as much reason for distrust as for respect" [14].

\section{B. The Honeymoon Period}

Caught in the wars though, this decade was also called the US-Japan honeymoon period due to the research of Charles Wordell that at this stage "Japan imitates America," [15] and “America Romances Japan." [16] Consequently, there were more than a hundred popular stories and novels of Japan written by the world known writers, such as Lafcadio Hearn, John Luther Long, creator of Madame Butterfly, and the intriguing "Onoto Watanna"-also known as Winnifred Eaton Babcock-"both of whom wrote formula romance fiction that included Japan as a new ingredient." [15] Thus novels and stories published in this period basically formed the classical western stereotype towards the Japanese woman, which meanwhile had a great influence on their modern images. Therefore, it was also the most important period for the American literature with a theme of Japan.

\section{Lafcadio Hearn}

Patrick Lafcadio Hearn (1850-1904), known also by the Japanese name Koizumi Yakumo, was an international writer, known best for his books about Japan, different from most of the writers who wrote about Japan in his time, Hearn's best known books were mainly the collections of Japanese legends and ghost stories, on which he had a special interest. This particular obsession was, to a great extent, attributed to his complex and difficult life experience. According to Wordell's introduction on Hearn' bibliography,

Born to an Anglo-Irish father and Greek mother on the Aegean island of Lafcadion in 1850, Hearn grew up in Dublin, France, and England, finally arriving Cincinnati, Ohio, in 1869, impoverished and without family support. During a tragic childhood that seriously affected his later writings, Hearn suffered separation from his mother when she was confined, after two years of madness, in 1854. Raised 
under the nominal guardianship of a widowed great-aunt, he attended boarding schools for nearly ten years, and was blinded in his left eye during this period. At the age of eighteen he was abandoned by his aunt, and spent some time living with a former family maid in London. In the twenty years between leaving England and arriving in Japan in 1890, Hearn worked as a newspaperman and author, traveling extensively throughout America, Canada, and the French West Indies [17].

However, Japan was like a wonderland to him owing to the numerous legends and ghost stories among the folks. So Wordell regarded: "While Hearn died a Japanese citizen, he was truly an American author. He did his initial writing in America on American topics, and aimed at an American audience with his writings on Japan, which found ready circulation in American periodicals as well as in often reprinted collections" [18].

Unlike many writers who succeeded him writing the love formula between the western man and the Japanese woman, Hearn has truly lived in Japan for many years and died on this land, he had a real love of the Japanese culture and respected it very much. Therefore, he did not project too much American value upon the Japanese women and instead, dig for the inner deeper mental world of them.

A good example in case is "Ingwa-Banashi," a short story presents the readers the jealousy of a dying woman:

The woman, a daimyo's wife, called the most beautiful of her servants to her as she lay near death, and asked the girl to marry the daimyo and be a good wife to him. The girl was confused, and the confusion increased as the old woman asked for a pick-a-back ride. As the old woman mounted the girl, she slipped her hands into the sides of the girl's kimono, grabbed her breasts, and shouted that that was what she had wanted all along. ... after death the wife's hands remained fused to the girl, and though the arms were cut away, the blackened hands dug painfully into the girl's breasts during the early morning hours so long as she lived [19].

Contrast to the dark side of a woman's heart, Hearn was also good at describing the sweetness of the Japanese woman. In the story of "Haru", he wrote:

Haru was brought up, chiefly at home, in that old-fashioned way which produced one of the sweetest types of woman the world has ever seen. This domestic education cultivated simplicity of heart, natural grace of manner, obedience, and love of duty as they were never cultivated but in Japan. Its moral product was something too gentle and beautiful for any other than the old Japan society... [20].

On treating the topic of a woman who was willing to undertake a career as a geisha, Hearn also showed a different perspective with other writers on the similar theme. He did not stand at the highest point of the Western moral system to "attack the system that forced the highly-born heroine of 'Kimiko' into a life of public entertainment, yet he stressed the self-sacrifice that the girl make in refusing to marry a young man of high status." [21] The virtue of self-sacrifice is reinforced in Hearn's most famous Japanese ghost stories collection, Kwaidan, "which included numerous instances of women who sacrificed themselves for love of a husband or child" [22].

\section{John Luther Long}

John Luther Long was the "father" of Madame Butterfly. He created this classical image of the Japanese woman in 1898 after his first try in novel Miss Cherry Blossom of Tokyo. But it was Puccini that eventually brought this story to fame by adapting it to the Italian opera Madame Butterfly. Unlike Hearn who lived in Japan for many years and died there, Long even never visited Japan nor did he respect the Japanese people. In his works, a strong American image was projected onto Japan. Although he agreed with Hearn that the Japanese women possess the "simplicity of heart, natural grace of manner, obedience, and love of duty," [23] he demeaned them with Western prejudice, interpreted them with an American model and judged them by the American value standard. Therefore, "finally, the impositions of the West were depicted as sexual assaults" [23].

The tale of Madame Butterfly - published in the Century Magazine in 1898-was derived from the 1888 autobiographical novel Madame Chrysanthem by the French naval officer Pierre Loti. According to Wordell, the story is mainly about:

Lieutenant B. F. Pinkerton of the United States Navy, regretting his transfer to Japan from a Mediterranean post, decided to relieve the tedium by "marrying" a Japanese girl during his tour of duty. With little regard for the sixteen-year-old Butterfly's role in Japanese society, Pinkerton excluded her relatives from his house and precipitated her removal from the family records. Long showed no mercy toward Pinkerton for isolating the girl from her culture. Because ancestor worship and filial devotion were the motives underlying Japanese society. After he left, Butterfly bore a son, nicknaming him 'trouble' in the ironic fashion of condition that Pinkerton had as his trademark. In believing that Pinkerton would come back, Butterfly refused a number of suits from Japanese men. Pinkerton married a girl of his own race, when Butterfly learned of the marriage she nearly killed herself. [24] The story ends with the words: "When Mrs. Pinkerton called next day at the little house on Higashi Hill it was quite empty" [25].

\section{Winnifred Eaton Babcock}

Winnifred Eaton Babcock (1879-1954) was a female writer, a mixed-blood of a British merchant and a missionary-educated Chinese woman. Owing to her half Asian blood, Babcock was able to pretend herself as a Japanese and wrote under the pseudonym "Onoto Watanna". Most of her novels are Japanese love-romance which were widely read, made her "as much a phenomenon as an author". Her novel A Japanese Nightingale was a great commercial success and was praised as "the most charming and delightful story that had ever come out of Japan" by the article appearing in the weekly of her publisher, but it is The Heart of Hyacinth that is considered to be her true masterpiece.

There are two exceptional qualities of Babcock's works. One is that being as a female writer, she was more skilled at depiction of "love affairs, love dialogues, and the innocent lovemaking that she allowed the reader to observe." Therefore, she developed a unique writing style, somewhere between Hearn and Long, that integrated love stories into historical settings such as the Meiji Restoration and the 
post-Restoration decline of the feudal lords. [26] The other one is her Eurasian complex nearly appeared in every story that she fancied. "Her own sense of her uniqueness as a half-Asian, half-European North American, free to invent herself and to 'pass' as whatever she pleased-even Japanese-allowed her to envisage the 'two types of beauty', Western and Eastern, expressed in one woman." [27] The image of the Eurasian in A Japanese Nightingale was described as:

A cheap girl of Tokyo, with the blue-glass eyes of the barbarian, the yellow skin of the lower Japanese, the hair of mixed color, black and red, the form of a Japanese courtesan, and the heart and nature of those honorably unreliable creatures, alien at this country, alien at your honorable country, augustly despicable-a half caste [28].

Besides the appearance and personal identity, the Eurasian complex also shows in the triangle romantic relationship the heroine involved between an Asian guy and a Westerner, while the latter one was always preferred and a happy ending could be reaped at the end of the story.

"Although writers such Babcock continued to produce Japanese love romances into the 1910s, American writer had begun as early as 1901 to question the fairyland image of Japan." [29] In 1905, Japan-the gentle and submissive Oriental woman in the Americans' eyes, gave Russia-the same Western power as the US, a straight blow-the Victory of the Russo-Japanese War, which made the United States begin to alert and re-examine this pretty doll in its arms.

\section{MOANING FOR THE LOSS OF BUTTERFLY IN THE PRESENCE OF NEW WOMAN: 1905-1924}

In 1905, the Russo-Japanese War broke out. Although this was not Japan's first war of aggression, unlike the Sino-Japanese War a decade ago, last time, Japan's target was China and Korea, the same oriental nation, while this time, the object of war was Russia, the Caucasians like the United States and other Western powers. Like his own brother had been beaten, the U.S. felt a hint of crisis and alertness, which grew quickly into a strong feeling of anxiety or even a fear to some extent in the fast development of Japan's politics and military forces. This fear had finally evolved into the "yellow peril" toward the Asians in the background of a large number of Japanese immigrating to the U.S. West Coast. And one of the threats to America from Asia, according to Wordell, "was that of war, a threat that only Japan had the military might and social cohesion to raise" [30].

As a result, this negative sentiment affected the image of Japanese woman in the American Literature. The once-popular love romances between Western men and Japanese women began to fade from public's vision. And that classical image of Madame Butterfly was gradually turning into "mothers and wives who were willing to make great sacrifices in order to insure the military success of their nation" [31].

\section{A. The Breath of the Gods (1905)}

The Breath of the Gods reflects the change of the American view of the Japanese women in the context of that history. The story is mainly about Yuki, a partially Westernized, Christianized, and liberated Japanese girl left her French boyfriend with Russian blood for the need of her country and married Hagane, the Japanese minister of war. Seeing from Yuki's choice during the war, that the Japanese woman no longer chose the Western man as her husband, the traditional love formula was broken, so was the happy ending that the two wedded happily together. In this story, Yuki would rather kill herself than return to her western boyfriend. Although it still didn't escape from the cliché of Madame Butterfly, the heroine's motive for suicide was completely different-not for the abandon of her Western man, but for the strong will of leaving him. And the Western man, who can always walk away with no harm to himself in the previous romances, ended up madness, very miserable indeed. As Yuki expressed it: "I am not myself; I am what my ancestors, my parents and my country have made me; I am only one shivering mote of dust in my country's shining destiny" [32]. The Russo-Japanese War made the Americans see for the first time the fervent love and loyalty Japanese women had toward their country and tradition, as well as the qualities of boldness and independency they possessed under the pressure of wars, which were very different from what they have found in Madame Butterfly.

\section{B. Broken Butterflies (1924)}

Toward the change the Japanese women have made during the wars, Westerners' attitude is regrettable. They prefer that gentle, obedient and submissive "butterfly" before the Russo-Japanese War, and refuse to see the gradually westernized Japanese women in the process of Japan' imitation of the US. In Broken Butterflies, the author Henry Walsworth Kinney initially assumed the orient feminine and sexual, as a result the hero of his book, Kent, fancied all women on this land as "butterflies". In contrast to his fantasy, an American friend commented to Kent: "You know they get all kinds of new ideas, these girls, Socialism, free love, careers of their own, art, literature, foreign husbands, it may be one fad or another, anything." [33] Hence, the name of the novel Broken Butterfly implies for the Japanese women who want to involve in society and take them as "poor little butterflies, broken on the wheel." [34] His idea of the Japanese women is clearly illustrated in the statement he made after he saw the death of demonstrators, including his friend Sadako Adachi, who protest against militarism:

But these girls, these infinitely delicate and beautiful beings, made for sunlight, and fragrance, and flowers; but they are drawn, attracted into the whirl and whir of the wheels of our civilization, and they hurt them, tear and mangle them, in mind, in spirit, or in body, and cast them forth... Like that [gesturing to dead Sadako], dead, crushed-broken butterflies [35].

Kent involved in romance relationships with several Japanese women, but found out none of them was the butterflies he had been looking for. Such setting, as Wordell puts it, "may have indicated Kinney's awareness, conscious or unconscious, that Japan could no longer be defined as sexual, mysterious, and available" [36].

Not only the image of women, the focus of the novels has 
also changed. "Many American writers of fiction directed their attention away from Japanese women and social conditions toward Japanese men and the political goals of the Japanese state" [31]. In the newspapers, there were even some writers who imagined wars between Japan and the United States. This negative trend ended abruptly after the passage of the Oriental exclusion provision of the immigration Act of 1924, which forbade the Asians from immigrating to the US. From then on, Japan began to disappear from the American literature.

\section{ICE AGE: 1925-1945}

\section{A. 1925-1931 Neglect Japan}

From 1925 to 1931, Japan was neglected by the US. There were few books writing about Japan, even from the political or military perspectives. Japan was completely ignored by the US. When the Americans realized that their oriental butterflies were no longer the obedient dolls in their hands, but the mothers and wives of a fearful military nation, they chose to close their eyes and refused to see the true faces under their delicate masks of dolls. It was not until 1931, Japan launched the Mukden Incident in the pursuit of a full-scale invasion of China, made the Americans reluctantly though, put their eyes back to Japan.

\section{B. 1932-1945 Ignore the Women}

As the Americans put Japan back to their sight, rich and varied literature regarding Japan emerged again. The four major modes according to the conclusion of Wordell were "spy thrillers, pro-Chinese writing, semidocumentaries, and historical novels." [37] However, regardless of the types of the novels, the Japanese women had been barely seen in the various stories made by the Americans. And the romance between American man and Japanese woman did not regain its popularity until the 1950s after the World War II.

\section{FALL IN LOVE AGAIN: 1946-1953}

After World War II, Japan's image in America has fallen into the abyss. Sayonara, "a book published in 1953 and stayed on the bestseller lists for five months" [38] was written by James Michener under this historical background. As it is depicted in this novel: "Dirty streets, little paper house, squat men and fat round women," [39] which has formed a "usual post-war prejudices about Japan." [40] Under its influence, the image of the Japanese women has also flopped badly. The gentle butterflies flying in the American men's oriental dreams in the late $19^{\text {th }}$ century had all gone. When they were facing the Japanese women again after the Pacific War, the first idea that came to their mind was: "How can our men-good average guys-how can they marry these yellow girls?" [41] However it wouldn't last for long until they encountered a doomed, beautiful Japanese girl, who taught them about arts and flowers, taught them how to understand the Japanese culture, how to look at this world with the oriental philosophy and mostly importantly, how to love.

In Sayonara, Hana-ogi is this girl. She changed the hero, Lloyd Gruver's prejudices about Japan, and he ultimately signed: "All the problems we used to laugh about as being so strange-so unlike America-I saw explained this afternoon. The Japanese were no different from us." [42] So in front of such a woman full of oriental charm, the US once again "falls", forgot about the Japanese soldiers who once threatened militarily, fell in love again with Japan. And finally by the physical combination of this couple achieved the fusion of the Japanese culture and American culture: "There was now no thought of Japanese or American. We were timeless human beings without nation of speech or different color. ... You find a girl as lovely as Hana-ogi-and she is not Japanese and you are not American." [43] But even so, the novel still did not get rid of the cliché that American man abandoned his Japanese woman and returned to the woman of his own nation, as Gruver's returned to the US for promotion. However, the emotional status of the heroes when they were leaving Japan has undergone substantial changes. Pinkerton had no any trace of regret or compassion toward this woman and her country when he abandoned Butterfly, which was in contrast to Gruver's nostalgia. One word "sayonara" expresses his reluctant feeling of leaving and the genuine love to Hana-ogi and also to the whole of Japan. In saying sayonara, according to Littlewood, Gruver was actually saying it to all the seductions of the exotic: [44] "To the alley and the canal and the little houses and the pachinko parlour and to the flutes at night-sayonara. And you, Japan, you crowded islands, you tragic land-sayonara, you enemy, you friend." [45] The "enemy" refered to Japanese man while the "friend" refered to Japanese woman. So, to some extent, it was the woman that saved Japan's image in the world. Just as Littlewood puts it: "She redeems a country tainted by the war and explains a culture that the west has been taught to despise" [44].

\section{CONCLUSION}

The Japanese woman, as the image of her country, is well known by the western countries through various kinds of love romances between a western man and a Japanese woman. The stories may be different, but the heroines are always the same one and only-Madame Butterfly, the most classical stereotype of the Japanese woman. She is not a real woman, but merely a reflection of western imagination and dreams toward the Orient. The US is doubtlessly one of the biggest dreamers owing greatly to his close relationship Japan. In spite of the Americans' wills, Japan did not stay content with this identity of Madame Butterfly. With the rise in both economics and military powers, Japan has witnessed the changes not only in its rank of the world but also in images of women that represents the country. By tracing the transformation from 1853 to 1953 , this paper attempts to prove that the changes of Japan's economic power, political role and military strength can contribute to the converse of its oriental national image by Edward Said's theory of Orientalism. The Japanese woman represents her country. In Orientalism, she has always been the object of an obscenity, never been faced straightly or correctly; the object that can be insulted, trampled or even raped by the Westerner's free wills and finally abandoned at any time if they are not needed. And for all these atrocities, the Japanese woman can do nothing but blindly accepts, silently obeys, no any trace of resistance, even commits 
suicide after being abandoned in order to remain loyal to her Western masters. This is a Japanese woman in the classical stereotype being widely favored by the Westerners. Just like Japan under the power of the US, as a student-an inferior role, it could be friended by the US. Even though it launched the Sino-Japanese war, it was still the "woman" under the body of the America. Nothing changed and affected the love between these two countries. But the Russo-Japanese War completely broke the US-Japan balance that established by the Americans. With the growth of Japan's national strength, the distance between these two countries was gradually narrowing down, which forced the US to face Japan straightly. Japan, at this point, to the West, as Pearl Buck stated in a 1935 preface to her regular book review column in Asia magazine: "the Orient has become part of the Occident and the Occident part of the Orient." [46] Japan gradually separated itself from its oriental attributes in the process of becoming strong. Meanwhile, the Japanese woman, who represented Japan's national image, had become masculine with the rise of Japan. During the Pacific War, the US could no longer disguise Japan as a woman and treated it like a master to his maiden, so the image of "Butterfly" had completely disappeared in the American literature. It was not until the defeat of Japan in World War II, after the US entered Japan as a victor, as the defeated and weak side, Japan retreated to its Oriental position, redressed its kimono, performed the role of geisha once again and finally won America's heart back to "her." Therefore, through tracing the transformation of the images of Japanese women in American Literature it is obvious that the "Orient" in terms of Orientalism was not always the same during the one-hundred-year Changes of the world. When it was weak enough to be oppressed it was the Orient. But once its national strength and military power grew, it was no longer considered as the Orient and the stereotypical image of the Orient was accordingly not justified.

\section{REFERENCES}

[1] I. Littlewood, The Idea of Japan, Chicago: Ivan R. Dee, 1996, p. 120.

[2] G. H. Preble, The Opening of Japan: A Diary of Discovery in the Far East 1853-1856, Norman: University of Oklahoma Press, 1962, p. 183.

[3] G. H. Preble, The Opening of Japan: A Diary of Discovery in the Far East 1853-1856, Norman: University of Oklahoma Press, 1962, p. 181.

[4] F. Harris, My Life and Loves, London: Virgin Books, 1964, p. 913-914.

[5] H. Clive, My Japanese Wife, New York: Frederick A. Stokes, 1902, p. 1.

[6] Ibid, 24, pp. 28-29.

[7] H. Norman, The Real Japan, New York: Charles Scribner's Sons, 1909, p. 174.

[8] W. E. Griffis, The Mikado's Empire, New York: Harper \& Brothers, 1876, p. 559 .

[9] I. Littlewood, The Idea of Japan, Chicago: Ivan R. Dee, 1996, p. 118.

[10] H. Clive, My Japanese Wife, NY: Frederick A. Stokes, 1902, p. 39.

[11] I. Littlewood, The Idea of Japan, Chicago: Ivan R. Dee, 1996, p. 143.

[12] C. B. Wordell, Japan's Image in America, Kyoto: Yamaguchi Publishing House, 1998, p. 109.

[13] C. B. Wordell, Japan's Image in America, Kyoto: Yamaguchi Publishing House, 1998, p. 139.

[14] C. B. Wordell, Japan's Image in America, Kyoto: Yamaguchi Publishing House, 1998, p. 140.

[15] C. B. Wordell, Japan's Image in America, Kyoto: Yamaguchi Publishing House, 1998, p. 92.
[16] C. B. Wordell, Japan's Image in America, Kyoto: Yamaguchi Publishing House, 1998, p. 94.

[17] C. B. Wordell, Japan's Image in America, Kyoto: Yamaguchi Publishing House, 1998, pp. 99-100.

[18] C. B. Wordell, Japan's Image in America, Kyoto: Yamaguchi Publishing House, 1998, p. 104.

[19] C. B. Wordell, Japan's Image in America, Kyoto: Yamaguchi Publishing House, 1998, pp. 101-102.

[20] L. Hearn, Kokoro: Hints and Echoes of Japanese Inner Life, London: Gay and Bird, 1896, p. 347.

[21] C. B. Wordell, Japan's Image in America, Kyoto: Yamaguchi Publishing House, 1998, p. 102.

[22] C. B. Wordell, Japan's Image in America, Kyoto: Yamaguchi Publishing House, 1998, p. 104

[23] C. B. Wordell, Japan's Image in America, Kyoto: Yamaguchi Publishing House, 1998, p. 110.

[24] C. B. Wordell, Japan's Image in America, Kyoto: Yamaguchi Publishing House, 1998, pp. 112-113.

[25] J. L. Long, Madama Butterfly, NY: Century Magazine, 1898, p. 86.

[26] C. B. Wordell, Japan's Image in America, Kyoto: Yamaguchi Publishing House, 1998, p. 124-125.

[27] J. Shoaf. The Mirror of Women: The Japanese Woman as Doll. The "Jap Doll" - Ningyô on the Western Toyshelf 1850-1940. [Online] Available: http://www.clas.ufl.edu/users/jshoaf/jdolls/jdollwestern/jappy3.htm

[28] W. E. Babcock, A Japanese Nightingale, New York: Harper \& Brothers, 1901, pp. 14-15.

[29] C. B. Wordell, Japan's Image in America, Kyoto: Yamaguchi Publishing House, 1998, p. 136.

[30] C. B. Wordell, Japan's Image in America, Kyoto: Yamaguchi Publishing House, 1998, p. 155.

[31] C. B. Wordell, Japan's Image in America, Kyoto: Yamaguchi Publishing House, 1998, p. 93.

[32] S. McCall, The Breath of the Gods, Boston: Little, Brown, and Company, 1905, p. 218

[33] H. W. Kinney, Broken Butterflies, Boston: Little, 1924, p. 63.

[34] H. W. Kinney, Broken Butterflies, Boston: Little, 1924, p. 262.

[35] H. W. Kinney, Broken Butterflies, Boston: Little, 1924, p. 322.

[36] C. B. Wordell, Japan's Image in America, Kyoto: Yamaguchi Publishing House, 1998, p. 188.

[37] C. B. Wordell, Japan's Image in America, Kyoto: Yamaguchi Publishing House, 1998, p. 200

[38] C. B. Wordell, Japan's Image in America, Kyoto: Yamaguchi Publishing House, 1998, p. 145

[39] J. A. Michener, Sayonara, New York: Random House, 1953, pp. 995.

[40] C. B. Wordell, Japan's Image in America, Kyoto: Yamaguchi Publishing House, 1998, p. 146.

[41] J. A. Michener, Sayonara, New York: Random House, 1953, p. 997.

[42] J. A. Michener, Sayonara, New York: Random House, 1953, p. 1050

[43] J. A. Michener, Sayonara, NY: Random House, 1953, pp. 1050-1051.

[44] I. Littlewood, The Idea of Japan, Chicago: Ivan R. Dee, 1996, p. 150.

[45] J. A. Michener, Sayonara, New York: Random House, 1953, p. 1113.

[46] C. B. Wordell, Japan's Image in America, Kyoto: Yamaguchi Publishing House, 1998, p. 199.

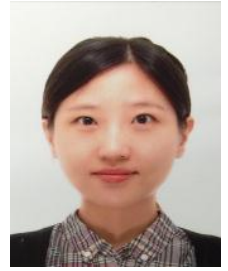

Li Ni is a member of IAEG. She was born in Tianjin, China on November 16, 1981. Ni obtained both her B.A and M.A. degrees in Tianjin University of Finance and Economics in 2004 and 2009, studying American literature. She continued her research on US-Japan comparative culture in International Christian University in Tokyo, Japan as a Ph.D. student sponsored by Japanese government (MEXT scholarship) in 2013

She became a lecturer in Tianjin University of Finance and Economics Pearl River College in 2009 teaching college English, American literature, and business English and published "Study on the Coordinative Development of Tourism in Jing-Jin-Ji Area Based on Industry Cluster Theory" on the 7th Euro-Asia Conference on CSR: Tourism, MICE, Hospitality Management and Education Session (Part II), August 25-27, 2011. Her current research interests are interdisciplinary, studying on the images of Japanese women in various media in "turn-of-the-century" U.S.

Ms. Ni is also a member of the Japan Association of Comparative Culture and ICU Comparative Culture. 